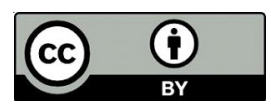

UDC 811.161.1'27

LBC 81.411.2-003
Submitted: 11.05 .2020

Accepted: 30.03 .2021

\title{
ETHNO-LINGUO-CULTURAL SPECIFICITY OF RUSSIAN OFFICIAL CONCEPT “COURT” IN EUROPEANIZATION ERA
}

\author{
Liudmila V. Popova \\ Miass branch of Chelyabinsk State University, Miass, Russia
}

\begin{abstract}
The article considers the nominative field of the concept "court" in the history of the Russian official language on the material of legislative documents of the $18^{\text {th }}$ century. The subject of the study is the relationship between the official segment of the concept "court" and the ordinary segment in the context of ethnic mentality. The hypothesis of ethno-cultural neutrality of the official segment has been tested. Special attention is paid to the evaluation nominations of the concept, their syncretsemia is revealed. The activity of non-terminological, morally and religiously marked nominations in relation to terms is found. Functional-semantic insufficiency of legal categories, their stable connection with moral and ethical categories in legal language consciousness is shown. Domination of semantic and conceptual constituents "truthful", "righteous / decent", "fair" over "legal" is established. The functional weakness of the conceptual sphere "law" is noted. The traditional ethno-specific perception of legal language consciousness is stated as predominance of moral and ethical concepts "truth", "righteousness", "fairness", "good", "conscience", "soul" over the "law". A high degree of ethno-cultural marking of the official segment of the concept "court" with a dominant meliorative valuation was noted. The analysis of the ordinary segment of the concept "court" in Russian paremiology revealed the above mentioned ethno-cultural concepts with a prevailing pejorative estimate. The coincidence of the justice pattern in the official and ordinary legal consciousness is noted.
\end{abstract}

Key words: concept "court", ethno-cultural concept, nominative field of concept, legal term, Russian legal language consciousness.

Citation. Popova L.V. Ethno-Linguo-Cultural Specificity of Russian Official Concept "Court" in Europeanization Era. Vestnik Volgogradskogo gosudarstvennogo universiteta. Seriya 2. Yazykoznanie [Science Journal of Volgograd State University. Linguistics], 2021, vol. 20, no. 4, pp. 50-63. (in Russian). DOI: https://doi.org/10.15688/ jvolsu2.2021.4.4

\section{ЭТНОЛИНГВОКУЛЬТУРНАЯ СПЕЦИФИКА РУССКОГО ОФИЦИАЛЬНОГО КОНЦЕПТА «СУД» ЭПОХИ ЕВРОПЕИЗАЦИИ}

\author{
Людмила Викторовна Попова \\ Миасский филиал Челябинского государственного университета, г. Миасс, Россия
}

\begin{abstract}
Аннотация. В статье рассмотрено номинативное поле концепта «суд» в истории русского официального языка на материале законодательных документов XVIII века. Описано соотношение официального сегмента концепта «суд» с обыденным сегментом в контексте этнической ментальности. Проверена гипотеза об этнокультурной нейтральности официального сегмента. Обнаружена синкретсемия и активность нетерми$\bar{\delta}$ нологических нравственно и религиозно маркированных номинаций концепта в отношениях с терминами. त. Показана функционально-семантическая недостаточность юридических категорий, их устойчивая связь с морально-этическими категориями в юридическом языковом сознании. Установлено доминирование семантических и концептуальных признаков 'правдивый', 'праведный / порядочный', 'справедливый' над признаком 'законный (правомерный)'. Охарактеризована функциональная ослабленность концептосферы «закон - право». Зафиксирована традиционная этноспецифичная установка юридического языкового созна() ния: приоритет морально-этических концептов «правда», «праведность», «справедливость», «добро», «со-
\end{abstract}


весть», «душа» над юридической концептосферой «закон - право». Констатирована высокая степень этнокультурной маркированности официального сегмента концепта «суд» с доминированием мелиоративной оценки. При анализе обыденного сегмента концепта «суд» в русской паремиологии выявлены те же моральноэтические этноконцепты с доминированием пейоративной оценки. Отмечено совпадение эталона правосудия в официальном и обыденном правосознании.

Ключевые слова: концепт «суд», этнокультурный концепт, номинативное поле концепта, юридический термин, русское юридическое языковое сознание.

Цитирование. Попова Л. В. Этнолингвокультурная специфика русского официального концепта «суд» эпохи европеизации // Вестник Волгоградского государственного университета. Серия 2, Языкознание. 2021. - T. 20, № 4. - C. 50-63. - DOI: https://doi.org/10.15688/jvolsu2.2021.4.4

\section{Введение}

Актуальность исследования заключается в необходимости выявления этнокультурных факторов, влияющих на развитие русского юридического языкового сознания и отражающихся не только в юридических номинациях, которые выражают профессиональный взгляд на общественно-правовые реалии, но и в номинациях ценностного характера, которые выражают этнокультурные константы / доминанты - ключевые концепты лингвокультуры (о терминах см.: [Степанов, 2001; Карасик, 2002]), определившие специфику русской правовой картины мира.

Многие представители гуманитарных наук придерживаются концепции русского правового нигилизма, в основе которой лежит признание изначальной противопоставленности права и морали в национальном мировоззрении. Например, в работе социолога и этнопсихолога К. Касьяновой «О русском национальном характере» одной из центральных является мысль о том, что социальные институты русского общества извне задаются государством, оформляются законами и обосновываются принятой в государстве идеологией, а изнутри они «стоят» этническими моделями поведения, не имеющими к этой последней никакого отношения [Касьянова, 1994, с. 46]. Аналогичные утверждения обоснованы и лингвистами: достаточно сослаться на труды Н.Д. Арутюновой, В.В. Колесова, И.Б. Левонтиной, А.Д. Шмелева, Ю.С. Степанова, в которых констатируется приоритет моральноэтических концептов «правда», «справедливость», «совесть» над концептами, формирующими концептосферу «закон - право» [Арутюнова, 1999; Колесов, 2006; Левонтина, Шмелев, 2000; Степанов, 2001]. Наблюдается аб- солютизация роли русского антилегализма, воплощенного в национальном языковом сознании (языковой картине мира), разъединенность обыденного (этического) и официального (профессионального) правосознания, отраженная в русской паремиологии как негативное отношение к закону и чиновникам - «судейским», противопоставление правосудия и суда совести, формального права и правдысправедливости [Воркачев, 2009, с. 15-16].

Этнокультурная специфика языка русского права и юридического языкового сознания остается малоизученной. Официальный сегмент концепта «суд» в соотношении с национальной лингвокультурой обычно не привлекает внимания ученых в силу априорности концепции русского антилегализма. На материале паремий описаны обыденные представления о суде [Кузнецова, 2001]. Русский концепт «суд» $\mathrm{X}-\mathrm{XV}$ вв. рассмотрен в терминологическом аспекте [Лыкова, 2005]. Исходной гипотезой нашего исследования является предположение о противопоставленности официального и обыденного сегментов концепта «суд», об отсутствии или о низкой степени этнокультурной обусловленности официального сегмента. Следует подвергнуть сомнению мысль о полной дистанцированности официального правосознания от этнической ментальности: русский юридический язык изначально входил в общенациональную языковую среду, субъекты правотворчества естественным образом оперировали категориями и концептами национального языкового сознания. Проблема изучения этнокультурной обусловленности языка права была поставлена славистами В.В. Ивановым и В.Н. Топоровым, указавшими на запечатленную в языке архаичную спаянность славянских понятий права, справедливости и закона, которые имели 
сакральный статус [Иванов, Топоров, 1978, c. 234-235].

Объект нашего исследования составляет номинативное поле концепта «суд» в истории русского делового языка как отражении юридического языкового сознания. Предмет изучения - соотношение официального сегмента концепта «суд» с обыденным в контексте этнической ментальности.

\section{Материал и методы исследования}

По нашему мнению, глубокое и объективное изучение русского правосознания невозможно без двустороннего анализа: наряду с обыденным его слоем необходимо анализировать официальный слой, выраженный в массиве юридических документов разных эпох. При выявлении закономерностей развития юридического языкового сознания внимания заслуживают в первую очередь нормативно-правовые акты, регламентировавшие принципиальные вопросы жизни государства и общества. Использование текстов юридических документов в качестве первоисточников дает основания для объективных выводов об эволюции юридической языковой картины мира и языковой этнокартины мира в целом. Диахроническое изучение способов номинации правовых понятий позволяет выполнить лингвистическую реконструкцию категорий правового мышления. Комплексная методика ориентирована на верификацию связи правового мышления с этнической ментальностью: интент-анализ документов, контекстологический и валентностный анализ, дефиниционно-компонентный анализ номинативных средств концепта «суд», их лингвокогнитивная и лингвокультурная интерпретация.

Отбор языковых средств при создании нормативно-правовых документов имеет первостепенное значение, поскольку текст юридического документа выполняет регулятивную функцию, формируя модели поведения субъектов права. Концепт «суд», закрепляемый юридическим языком, с одной стороны, является базовым в профессиональной деятельности, с другой - обусловливает восприятие суда остальными субъектами права. Можно предположить, что для создания официального сегмента концепта «суд» законода- телями производился отбор языковых средств, выражающих эталонные в юридической сфере свойства, качества: нейтральных либо собственно юридических номинаций, не имеющих этнокультурной маркированности либо проявляющих ее в низкой степени. Цели исследования - выявление принципов отбора законодателями речевых средств для формирования официального сегмента концепта «суд», верификация этнокультурной обусловленности данного концепта с помощью лингвокогнитивной и лингвокультурной интерпретации.

На материале текстов памятников русского права реконструируем формирование концепта «суд». Активное языковое формирование данного концепта происходило в XVIIXVIII вв., особенно в периоды правления Петpa I и Екатерины II - эпоху европеизации. Юридическая сила используемых в исследовании нормативно-правовых актов распространялась с момента издания по XIX в., отчасти до Октябрьской революции 1917 г., поэтому можно говорить об устойчивости концепта «суд» в юридическом языковом сознании и политическом дискурсе на протяжении примерно 200 лет. В законодательстве Петра I регламентация работы судебных органов включала и требования к судьям. Этой проблеме посвящен ряд указов и комплексных правовых документов. К последним относятся «Уставъ Воинскій» 1716 г. в двух частях «Артикулъ воинскій съ краткимъ толкованіемъ» и «Краткое изображеніе Процессовъ или Судебныхъ тяжебъ» (ПСЗРИ 1, т. V, № 3006) ${ }^{1}$; «Генеральный Регламентъ или Уставъ» 1720 г. (ПСЗРИ 1, т. VI, № 3534), «Регламентъ или Уставъ Главнаго Магистрата» 1721 г. (ПСЗРИ 1, т. VI, № 3708), в которых отражены нормы уголовного, процессуального и государственного права. Екатериной II были введены «У чрежденія для управленія Губерній Всероссійскія Имперіи» 1775 г. (ПСЗРИ 1, т. ХХ, № 14392), определившие новые принципы деятельности административной и судебной власти; «Уставъ Благочинія или Полицейскій» 1782 г. (ПСЗРИ 1, т. XXI, № 15379), установивший нормы деятельности полиции и ее взаимодействия с судебными органами. Рассмотрим языковые средства, используемые в законодательных текстах для регламентации норм деятельности судебных органов и их сотрудников. 


\section{Результаты и обсуждение}

1. Номинации концепта «суд» в эпоху Петра I. Именной указ «О порученіи Правительствующему Сенату попеченія о правосудіи, объ устройств Б Государственныхъ доходовъ, торговли и другихъ отраслей Государственнаго хозяйства» от 2 марта 1711 г. (ПСЗРИ 1, т. IV, № 2330) содержит требование правомерной деятельности судебной системы, семантическим центром при этом выступают квалификативные лексемы, создающие эталонный образ суда - нелищемерный и праведный:

(1) Судъ им'ть нелицемłрный, и неправедныхъ судей наказывать отнятіемъ чести и всего им Њнія, то жъ ябедникамъ да посльдуетъ (п. 1).

Юридическая номинация правосудие в названии указа коррелирует с формулами нелицемерный суд и (не)праведные судьи в тексте, выполняющими пояснительную функцию, что свидетельствует об отождествлении в юридическом языковом сознании соответствующих им когнитивных структур: правосудие понималось как «праведность», «нелицемерность». В последующих законодательных актах поддержана традиция употребления праведный(-о) и нелицемерный(-о) в отношении судебной деятельности. В комплексном документе «Регламент или Устав Главного Магистрата» предписано:

(2) чтобъ въ Магистратахъ везд' судъ и розыскъ по дь'ламъ быль праведный по Уложенію и по Его Великаго Государя указамъ (ПСЗРИ 1, т. VI, № 3708, гл. IX).

В данном случае эксплицитная корреляция праведный суд / правосудие отсутствует, что свидетельствует о самодостаточности понятия «праведный» в юридическом языковом сознании для характеристики правомерности. В именном указе «О должности Генераль-Прокурора» от 27 апреля 1722 г. (ПСЗРИ 1, т. VI, № 3979) генерал-прокурору предписано следить за тем, чтобы Сенат праведно и нелицем врно поступал (п. 2); праведно исправлять (п. 7) (то есть судить) должны были надворные и земские суды под присмотром фискалов. При Екатерине II в законодательных актах возникла формула точно и нелицемерно отправлять должность, характеризующая эталонную модель поведения чиновников, в том числе судебных. В Манифесте о введении в действие «Учреждений для управления Губерний Всероссийской Империи» данная формула коррелировала с прямым обозначением правомерной судебной деятельности - правосудие.

Вариантной к формуле праведно / нелицемерно поступать / исправлять при определении правомерности сенатской и прокурорской деятельности в законодательстве Петра I была формула истинно и ревностно поступать / отправлять, в которой первый квалификативный компонент семантически сближен с праведно / нелицемерно, а второй выполняет комплементарную функцию для усиления императивности предписания:

(3) дабы Сенать < ..> истинно, ревностно и порядочно <..> по Регламентамъ и указамъ отправляль, развъ какая законная причина къ отправленію, ему пом'Њшаеть (указ № 3979, 1722 г., п. 1);

(4) дабы въ своемъ званіи истинно и ревностно поступали, а ежели кто въ чемъ преступитъ, то оныхъ судить въ Сенат $<<$...> - о прокурорах (п. 3).

Кроме отмеченных формул номинации правомерности судебных процессов использовалась формула порядочным образом / порядочно отправлять (и с другими глаголами, обозначающими судебные действия):

(5) чтобъ процессы порядочно и надлежащимъ образомъ отправлялись («Краткое изображение Процессов или Судебных тяжеб», гл. I, п. 7);

(6) доказь или основаніе дњкла порядочнымъ образомъ окончается (ч. III, гл. I «О приговорахъ», п. 1);

(7) дабы Сенать < .. > истинно, ревностно и порядочно $<\ldots>$ по Регламентамъ и указамъ отправляль, разв' какая законная причина къ отправленію, ему пом'Њшаеть (указ № 3979, 1722 г., п. 1).

В законодательных текстах возникал семантико-когнитивный параллелизм между юридическим судом и Божьим судом, основанный на двуплановости формул праведный суд, нелицемерный судья. Так, именным указом «Объ отм'нъ въ судныхъ дълахъ очныхъ ставокъ, о бытіи вм'сто оныхъ расспросу и розыску, о свид中теляхъ, объ отводы оныхъ, о присяг $\mathbf{k}$, о наказаніи лжесвид女телей и о пошлинныхъ деньгахъ» от 21 февраля 1697 г. 
(ПСЗРИ 1, т. III, № 1572) регламентировалась процедура церковной присяги истца, ответчика с целью проверки их показаний при отсутствии у суда других убедительных доказательств:

(8) претить истцомъ и отв топриводства накрњпко, чтобъ они, памятуя въ себстрахъ Божій и праведной Его Судъ, къ крестному

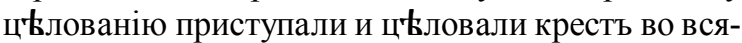
кой правдњ безо всякаго душевредства (п. 8).

Религиозная формула праведный Суд ассоциативно связана саналогичной юридической формулой. Судейская присяга в «Кратком изображении Процессов или Судебных тяжеб» (п. 13), получившем применение в различных отраслях права, формально выразила принципы антикоррупционности, объективности и правомерности рассмотрения дела и вынесения приговора, при этом традиционно семантический акцент сделан на нелицемерности:

(9) ни для дружбы или склонности, ни подарковъ или дачей, ниже страха ради, ни для зависти и недружбы, но токмо едино по челобитью и отв Łту, по Его Царскаго Величества, Нашего Всемилостив Њйшаго Царя Государя воинскимъ пунктамъ, правамъ и уставамъ приговаривать и осуждать хощемъ право и нелицем'рно.

Присяга заключена в традиционную религиозную рамку, при упоминании Бога использован перифраз эталонного значения нелищемерный Судия, с помощью которого реализован семантико-когнитивный параллелизм с регламентацией деятельности судей в формуле приговаривать и осуждать право и нелицемерно: «<... клянемся Всемогущимъ Богомъ $<\ldots>$ такъ какъ намъ отв страшномъ суд' Христовњ. Въ чемъ да поможетъ намъ Онъ, нелицемłрный Судия». Таким образом, в юридическом языковом сознании юридический суд имел идентичную с Божьим судом характеристику праведный, что придавало первому религиозную коннотацию.

$\mathrm{B}$ «Кратком изображении Процессов или Судебных тяжеб» установлены критерии выбора и принципы деятельности судей, нормы судопроизводства, формально сводимые к законопослушности и правомерности (гл. I «О суд' и судіяхъ»). В первую очередь профессионализм судьи ставится в зависимость от добросовестности (честности):
(10) Судъ всегда изъ н'котораго числа честныхъ особъ сочиненъ бываетъ, которымъ отъ высокаго начальства власть и мощь во управленіи правосудія дана (п. 2).

Очевидно, в данном документе формула честная особа выполняет ту же функцию, что праведный судья (например, в упомянутом указе № 2330, 1711 г.), то есть квалификативные прилагательные честный и праведный функционально идентичны, поскольку объединяющим понятием формально выступает «правосудие» (правомерное судопроизводство). Затем отмечена необходимость юридической компетентности (знания прав законов) и способности устанавливать реальность фактов, рассудительности (разуметь правду):

(11) Хотя обще всњмъ судьямъ знать надлежить права и разум Њтъ правду, ибо неразум'ющій правды, не можетъ разсудить ея (гл. I, п. 7).

Оговаривалась возможность судебных ошибок (погрешений) и обязанность наблюдателей (аудиторов) корректировать процесс разбирательства - обеспечивать достоверность, законность, правомерность (правду): «къ правдь основательно приводить» (гл. І, п. 7), «сущею правдою въ д '九л' поступать» (п. 8).

Наряду с перечисленными номинативными средствами, в законодательстве для регламентации требований к сотрудникам судебной системы вводились речевые формулы с семантическим центром совесть, формально соотносимые с понятиями законопослушности, правомерности. В «Кратком изображении Процессов или Судебных тяжеб» при характеристике обязанностей судей (наряду с остальными участниками процесса) действовать в рамках законов во время судебных заседаний использован оборот «напамятовать свою совсьсть при отправленіи д女ла» (гл. I, п. 10). В прямой связи с формулой напамятовать совесть находится антонимичная формула забыть совесть, использованная для регламентации поведения свидетеля:

(12) понеже когда онъ присягаль, тогда уже присяги своей, разв з забывъ свою сов ъсть, не нарушить, но толь паче правду донесетъ $<\ldots>$ (ч. 2, гл. ІІІ «О свид'ьтеляхъ», п. 6). 
«Устав Воинский», нормы которого широко применялись в уголовном, процессуальном и государственном праве, определил требование быть людям доброй совести к должности фискала, выполнявшего надзорные функции, в том числе при решении юридических ситуаций, проведении судебных процессов (обвинитель в суде):

(13) Въ семъ званіи будущимъ надлежить быть людямъ добрыя совъсти предъ Богомъ, дабы никому не манить и никого напрасно не оскорблять, а особливо безпорочно служащихъ (гл. XLII).

\section{2. Номинации концепта "суд" в эпоху}

Екатерины II. Актуализация понятия «совесть» отражена в обозначении учрежденного Екатериной II в 1775 г. губернского правоприменительного органа - совестного суда, а также при характеристике требований к судьям. Суды данного вида функционировали в России до 60-х гг. XIX в. (упразднены Сенатом), то есть около ста лет. Совестные суды рассматривали гражданские дела в порядке примирительной процедуры и некоторые уголовные (БЮС, 2001, с. 507). Целью судебных заседаний было примирение сторон (например, в споpe о разделе имущества между родственниками) или определение судьбы, в том числе защита, субъектов правонарушений, не представляющих значительной общественной опасности, когда полноценный преступный умысел отсутствовал (невменяемость, несовершеннолетие, нравственный или физический недостаток, суеверие, неблагоприятное стечение обстоятельств и т. п.). В связи с этим при вынесении решений суду следовало не только учитывать правовые нормы, но и соблюдать принцип «естественной справедливости». Идею основания этого суда обычно связывают с влиянием на Екатерину II идей прогрессивных французских мыслителей: Ш. Монтескье, Д. Дидро, Вольтера, Ж.-Ж. Руссо. Не менее значимыми в данный период, с нашей точки зрения, были константы русской ментальности, отраженные и в официальном правосознании предшествующего времени, в частности доминанта совести. В законодательном тексте наблюдается корреляция термина совестный суд с названием нравственного качества судьи совестный и названиями ряда взаимообусловленных профессионально значимых качеств:
(14) Въ Судьи Сов ъстнаго Суда Нам'ъстничества (Губерніи) опред‘ляется выборомъ каждаго Судебнаго мъста той Губерніи, одинъ къ тому способный, сов Һстный, разсудительный, справедливый и безпорочный человъкъ («Учреждения для управления Губерний Всероссийской Империи», п. 63).

Комплементарные отношения квалификативных прилагательных в данном ряду демонстрируют облигаторность высокой нравственности судьи и способности объективно оценивать факты на соответствие моральноэтическим нормам, в то время как формально подразумевается законопослушность судьи и правомерность деятельности суда. Возможно, кольцевая композиция «сов Встный <..> безпорочный» призвана подчеркнуть базисность духовных установок личности судьи для его рациональной профессиональной деятельности.

В систему сословных судов с 1775 г. до середины XIX в. входили расправы - суды для государственных крестьян, однодворцев, казаков, рассматривавшие мелкие уголовные и гражданские дела (БЮС, 2001, с. 461). В качестве критерия выбора претендентов на должность заседателей расправы, как и судей совестного суда, была названа нравственная безупречность - беспорочность, формально подразумевалась законопослушность, способность обеспечить правосудие:

(15) Верхней Расправы Засъдатели, да 8 Засъдателей Нижней Расправы <...> выбираются т中ми селеніями, кои составляють подсудное въдомство той Верхней Расправы, и не запрещается имъ избрать изъ Дворянъ, или ученыхъ людей, или изъ чиновныхъ людей, или изъ разночинцовъ, или поселянъ безпорочныхъ людей, чрезъ всякіе три года, и представляются Правителю, и буде за ними нłть явнаго порока, то Губернаторь дозволяеть имъ засъданіе («Учреждения для управления Губерний Всероссийской Империи», п. 75).

Как видно, развернутый ряд совестный, рассудительный, справедливый и беспорочный (п. 63) в данном случае редуцирован до беспорочный. Поскольку снижение требований к судье по уголовным и гражданским делам маловероятно, можно объяснить данное явление способностью последнего прилагательного выполнять общеквалификативную 
функцию, заменяя взаимосвязанные номинации: в юридическом языковом сознании беспорочным может быть совестный, справедливый, рассудительный человек.

Вариацией при юридической характеристике судьи словесного суда (для решения устных жалоб по гражданским делам и примирения сторон) были качества справедливости и добропорядочности:

(16) На основаніи учрежденій главы XX статьи 281-й, по окончаніи службы Судей Словеснаго Суда и выборныхъ, буде справедливостію и добропорядочными поступками то заслужатъ, даны имъ будуть оть городовыхъ д'єль похвальные листы» («Устав Благочиния или Полицейский», п. 175).

«Справедливость» в этом контексте, очевидно, включала и значение рассудительности, «добропорядочность» (добропорядочные поступки) обобщила значения совестности и беспорочности (в сравнении с п. 63, 75 «Учреждений для управления Губерний Всероссийской Империи»).

В нормативно-правовых актах Екатерины II в текстовой постпозиции, после концентрации морально-этических номинаций, реже встречаются блоки с использованием термина закон, определяющие необходимость юридической компетентности судебных чиновников:

(17) Вообще Губернскій Прокуроръ и Губернскіе Стряпчіе смотрять и бдЊніе им'ютъ о сохраненіи везд' всякаго порядка законами опред'学леннаго, и въ производств' и отправленіи

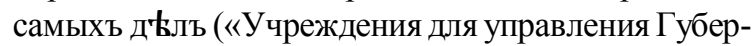
ний Всероссийской Империи», п. 404).

Следует отметить и наиболее обобщенную номинацию квалификативного характера лучшие люди, определявшую критерий выбора претендентов на должность судей надворного суда, который с 1719 г. по 60-е гг. XIX в. (с перерывами) в Санкт-Петербурге и Москве занимался решением уголовных и гражданских дел иногородних и разночинцев, не имевших недвижимости в столичных губерниях; состав суда назначался императором (БЮС, 2001, с. 310). Данный способ языковой оценки использован, например, в именном указе «О выборь лучшихъ людей, въ Надворный судъ изъ тьхъ Дворянъ которые останутся за опредъленными въ другіе чины» от 17 января 1722 г. (ПСЗРИ 1, т. VI, № 3878). В сравнении с представленными вариациями законодательной оценки эталонных качеств судьи можно считать формулу лучшие люди коррелирующей с формулами гипонимического типа нелицемерный / праведный судья, честная особа в синхронный период и совестный, справедливый, беспорочный, рассудительный человек, подразумеваемой добропорядочный человек (при соотнесении с добропорядочные поступки судей) в более позднем законодательстве; в формальном отношении можно видеть корреляцию с неиспользуемой номинацией типа законопослушный человек.

При анализе законодательных текстов мы отметили единичные случаи внутритекстового варьирования объективной и оценочной номинаций деятельности суда. В «Кратком изображении Процессов или Судебных тяжеб» решение суда, соответствующее законам и реальным фактам, названо справедливым (ч. I, гл. III «О челобитчик'», п. 3) и правомерным (ч. I, гл. IV «O отв $\mathbf{k} т ч и к \mathbf{k} »$, п. 1), соответствующий приговор - правомернblм (ч. I, гл. III «О челобитчик'な», п. 1) и пристойным (ч. II, гл. II «О признаніи», п. 3»). Приговор, вынесенный вопреки законам и реальным фактам, назван неправомернылм (гл. I «О суд' и судіяхъ», п. 8). Выше было отмечено соотношение термина правосудие в названии указа и оценочных номинаций нелицемерный суд и (не)праведные судьи в тексте (указ № 2330, 1711 г.). Данное явление свидетельствует о начале формализации концепта «суд».

Дефиниционно-компонентный анализ выявленных оценочных номинаций с учетом исторического состояния языка показывает, что в их семантической структуре правовая семантика соотносилась с неофициальной (морально-этической и религиозной) либо отсутствовала в исходном значении и возникала узуально в терминологическом употреблении. Описанное свойство будем называть синкретсемией. Вероятно, под влиянием естественной языковой синкретсемии формировалась и профессионально обусловленная синкретсемия (при условно-терминологической функции некоторых номинаций). В законодательных текстах между рядом оценочных номинаций 
возникли тесные связи благодаря интегральным семантическим признакам, в том числе отношения идентичности и синонимии.

Проследить проявление интегральных семантических признаков позволяет анализ лексикографической информации - сопоставление ретроспективных (СлРЯ XI-XVII) и синхронных (САР) толкований, более точно отражающих русское языковое сознание XVIII века.

К оценочным номинативным средствам с естественной синкретсемией отнесены: праведный, справедливый, право ('справедливо', 'законно, правомерно'), правда ('справедливость', 'законность, правомерность'). Нетрудно показать, что эти средства представляли собой органичный комплекс, имеющий древнее происхождение. С данной группой коррелировали термины правосудие и правомерный.

У лексической группы с центром праведный в древнерусском, старорусском языке сформировалась комплексная семантическая структура, в которой сосуществовали религиозный, моральный и юридический компоненты, последний указывал на справедливость, законные основания явлений, действий (СлРЯ XI-XVII, вып. 18, с. 102-104); эти же три типа значений были совмещены в XVIII в., у праведный, праведно выделяются семы 'истинность, правдивость', 'святость, безгрешность', 'законность' (САР, ч. IV, стб. 1044). Юридическое функционирование слов с корнем правед- зафиксировано в исторических словарях русского языка: приведен устойчивый в юридической сфере XVIII в. оборот судить праведно 'соответственно правде' (CAP, ч. IV, стб. 104), отмечены регулярная сочетаемость праведный суд, специализированное значение «суд (тяжба)» у субстантивированной формы праведное (СлРЯ ХІXVII, вып. 18, с. 104). У антонимичных лексем неправедный(-о) выделялась юридическая семантика «незаконный» в тесной связи с «несправедливый», иллюстрируемая в словаре, в частности, оборотом судьи неправедные (СлРЯ XI-XVII, вып. 11, с. 240). Отметим, что современное юридическое толкование номинации праведный недостаточно отражает ее роль в историческом кругу терминов: «правильный, справедливый, основательный» (ПРП, вып. 8, с. 657), но не «правомер- ный» (суд) и «законопослушный» (судья). Историки права XX в., таким образом, не придают терминологический статус данной номинации, хотя косвенно он отражен в указании на справедливость.

Лексическая группа с центром справедливый имела социально-оценочную семантику, отражающую как неформальную, так и официальную шкалу: справедливый «честный», справедливо «правильно», справедливость «отношение в соответствии с принятыми обычаями, законами, правилами» (СлРЯ XI-XVII, вып. 27, с. 82); «поступающий по правде, любящий правду» (CAP, ч. IV, стб. 1045). Эта связь трактуется в отечественной лингвистике как архаичная, исконная (выше была приведена точка зрения В.В. Иванова и В.Н. Топорова). Для языкового сознания XVIII в. приоритетна связь справедливость $n р а в д a$, транслируемая и в законодательстве (справедливый человек / судья, справедливость судей, справедливый приговор, разуметь правду, знать права - законы). В этом номинативном комплексе правда и право (приговаривать и осуждать право) тоже характеризуются древней синкретичностью, хотя в рассмотренных нами документах прав$\partial a$ имеет и узкое значение «достоверность»: все значения общеславянской лексемы *pravъ связаны со сферой упорядоченного, законосообразного в мире и обществе [Иванов, Топоров, 1978, с. 234-235]; у правьда, наряду со значениями «истина», «справедливость», «честность», «праведность», в древнерусском юридическом языке возникли значения «правило (юридическая норма)», «законоустановление», «свод правил, законов», «суд», «невиновность», «оправдание», «условия договора», «судебное испытание», «свидетель» и др. (ТСДЮТ, с. 82; САР, ч. IV, стб. 1043; СлРЯ XI-XVII, вып. 18, с. 98); правыи имело более 15 значений, в том числе моральных и юридических: «правильный», «истинный», «честный», «справедливый», «праведный», «невиновный», «относящийся к судебному рассмотрению» и др. (СлРЯ XI-XVII, вып. 18, с. 121-124).

К оценочным номинативным средствам с профессионально обусловленной синкретсемией отнесены: (не)лицемерный, честный, совестный, беспорочный, добропорядоч- 
ный, лучший, истинно, пристойный. Не обладая первичной юридической семантикой, они адаптированы в законодательных текстах формально для выражения взаимообусловленных эталонных качеств, формирующих законопослушность судей, и критериев правомерности судопроизводства. Сопоставление контекстных и лексикографических данных свидетельствует о семантической диффузности, интерференции номинаций. Именно поэтому они не могут быть названы собственно терминами. Такие номинации вступали в комплементарные (в основном интертекстуальные) отношения с номинациями первого блока (npaведный судья - честная особа, правомерный / пристойныгй приговор, приговаривать и осуждать право и нелицемерно, праведно поступать / исправлять - истинно поcтупать / отправлять) или выполняли компенсаторную функцию, в частности при несформированности термина. Несмотря на недостаточную формализованность, с помощью данных номинаций законодатель мог выразить необходимые оттенки в эталонном образе правосудия, доступно апеллируя не только к профессиональному, но и к обыденному языковому сознанию. По-видимому, коммуникативные цели доступности восприятия моделируемого образа и речевого воздействия осознавались как приоритетные по сравнению с формальным сообщением юридической информации.

В ряду таких номинаций на основе интегральных семантических и концептуальных признаков 'правдивый', 'праведный / порядочный', 'справедливый' представлены отношения идентичности, синонимии, гиперо-гипонимии, а в целом есть основания говорить о существовании в юридическом языковом сознании семантической сети, где каждый компонент был ассоциативно связан с другими (как внутри данного блока, так и с номинативными средствами блока «естественной синкретсемии»), что отражено в словарных толкованиях. Совестный-«сообразующий дела свои с чистой совестью» и в узко юридическом употреблении «по совести разбирающий / разбираемый» (о совестном суде, судье) (САР, ч. I, стб. 978). В русском языковом сознании производное добросовестный «праводушный, чистую совесть наблюдающий» (в ис- следуемом законодательном материале не отмечено) являлось синонимом к честныий и могло коррелировать с судья (см. иллюстративную часть статьи) (САР, ч. I, стб. 979). Честный в языковом сознании имело комплексную семантическую структуру, включающую взаимообусловленные значения «добросовестный, праводушный, который благополучием других занимается; почтенный, достойный, заслуживающий уважения» (CAP, ч. VI, стб. 726). Нелицемерный как антоним от лииемерный «скрывающий под видом добродетели пороки, притворяющийся добродетельным, набожным» (САР, ч. III, стб. 1197), «двуличный» (СлРЯ XI-XVII, вып. 8, с. 253) подразумевало в отношении человека, в том числе судьи, «недвуличный» (точнее, «честный, искренний», при этом «добродетельный, беспорочный»), в отношении суда «беспристрастный, справедливый» (СлРЯ XI-XVII, вып. 11, c. 163). Беспорочный «не имеющий порока» (САР, ч. V, стб. 132), «безупречный» (СлРЯ XI-XVII, вып. 1, с. 162) от порочныцй 'подверженный, причастный какому-либо пороку' (CAP, ч. V, стб. 132); порок - «преклонность души к злу, к делу, достойному порицания: отступление от правил добродетели», «противоположность добродетели, чистоте души» (САР, ч. V, стб. 131). Добропорядочный как производное от порядочный «степенный, исправный, наблюдающий порядок, следующий правилам нравственным» (CАР, ч. V, стб. 292) в языковом сознании XVIII в. также подразумевало соблюдение нравственных норм «добрый порядок во всем строго наблюдающий» (САР, ч. V, стб. 292) - о человеке. Порядочный «правильный» в исследуемом законодательном материале употреблялось для характеристики судебной деятельности, при этом в русском языковом сознании имело и значение «степенный, исправный, наблюдающий порядок, следующий правилам нравственным», ср. с порядочно «как надлежит, свойственно доброму, честному, степенному человеку; соответственно нравственности» (CAP, ч. V, стб. 292). Истинно «подлинно», «чистосердечно, нелицемерно» (САР, ч. III, стб. 320-321). Пристойный «приличный, соответствующий чему-либо» (СЦРЯ, т. III, с. 494).

Итак, результаты контекстологического, валентностного анализа и интент-анализа по- 
зволяют сделать вывод о том, что выявленный комплекс номинативных средств концепта «суд» воспринимался как органичный и коммуникативно-полноценный в юридическом языковом сознании. Этим объясняется сочетание, варьирование объективных и оценочных номинаций, доминирование последних. Их адаптация в законодательной речи, очевидно, позволяла реализовать комплексный коммуникативный замысел: сообщение юридической информации, обеспечение ее доступности и речевое воздействие.

Нравственно и религиозно маркированные значения при продуцировании и восприятии законодательных текстов, по нашему мнению, не были полностью отделены от юридических в силу устойчивых когнитивных связей в русском языковом сознании. Отношения морально-этических категорий к юридическим категориям в русском юридическом языковом сознании можно назвать комплементарными (дополнительными) и отчасти компенсаторными (заместительными).

Группа морально-этических номинаций позволяла не только сформировать образ высоконравственного судьи, справедливого суда, но и указать на облигаторную связь юридических и морально-этических категорий, то есть подчеркнуть зависимость законопослушности судьи от его нравственной безупречности, правомерности судебных процессов от их справедливости.

Можно говорить о специфическом взаимодействии морально-этических и юридических категорий, при котором в законодательной речи доминировала экспликация первых, а вторые не являлись функционально и семантически исчерпывающими в юридическом языковом сознании. В большинстве случаев указания на нравственные качества судьи и справедливость суда сопутствующего прямого обозначения законопослушности судей и правомерности суда в законодательстве нет. Даже при употреблении только терминологической номинации одного понятия ей сопутствовала оценочная номинация взаимосвязанного понятия: например, если правомерный суд назван правосудием, то в контексте присутствовала оценочная номинация честная особа в отношении судьи («Краткое изображение Процессов или Судебных тяжеб», гл. I «О суд
Показательной в этом отношении, на наш взгляд, является экспериментальная замена описанных оценочных номинаций использованными в текстах законодательных актов XVIII в. или потенциальными объективными (терминологическими) номинациями: праведный / нелицемерный суд - правосудие / правомерное судопроизводство, праведный / нелицемерный судья / человек доброй совести / совестный человек / справедливый человек - законопослушный судья, пристойный / справедливыц приговор - правомерный приговор, приговаривать и осуждать право и нелицемерно - приговаривать / осуждать правомерно / законно, «напамятовать свою сов \$сть при отправленіи д қла»-соблюдать законы / поступать правомерно при отправлении дела, судить правомерно и т. д. В представленных примерах графически выделены потенциальные - не реализованные в законодательстве номинативные модели (ср. с современным юридическим языком). Если в одних примерах экспериментальный термин отсутствует при наличии исторического аналога, как правило, более простого по структуре, но идентичного семантически (nриговаривать право - вместо правомерно / законно), то в других на месте нереализованного термина мы видим именно оценочные модели (праведный / нелицемерный судья / человек доброй совести / совестный человек / справедливый человек - вместо законопослушный судья; напамятовать сов \$cmь - вместо соблюдать законы / cyдить правомерно).

Сопоставление речевой законодательной практики с лексикографической информацией позволяет констатировать своеобразное избегание законодателем терминов группы «закон» для прямой номинации законопослушности судей и правомерности суда, а также самих законодательных актов, обобщенно называемых правами (см. «Краткое изображение Процессов или Судебных тяжеб» и другие документы). Например, словари русского языка XVIII в. содержат лексемы законопослуиник 'повинующийся закону' (СлРЯ XVIII, вып. VII), законоблюститель 'следящий за исполнением законов' (САР, ч. III, стб. 11), законохранитель 'следующий закону, исполняющий закон, хранящий закон' (CAP, ч. VI, 
стб. 585; СлРЯ XVIII, вып. VII) без атрибуции к правовой сфере. Подобные номинации могли найти применение и в русской законодательной речи, однако при несформированности предполагаемых терминов компенсаторную функцию выполняли оценочные номинации. Таким образом, наиболее активными в юридическом языковом сознании были семантические и концептуальные признаки 'правдивый', 'праведный / порядочный', 'справедливый', менее активным - 'законный (правомерный)'.

Дать полноценное объяснение выявленной тенденции, с позиции современного языкового сознания, сложно, но есть основания считать ее этнопсихологически обусловленной. Как было отмечено, юридические термины не были функционально и семантически исчерпывающими в русском юридическом языковом сознании. Концептосфера «закон право» была функционально ослабленной. На месте предполагаемых терминов мы видим номинации этноконцептов «правда», «праведность», «справедливость», «добро», «совесть», «душа», что вполне согласуется с известной приоритетностью морально-этических концептов над юридической концептосферой «закон - право» в национальном языковом сознании.

Возвращаясь к выдвинутой гипотезе, можно констатировать опровержение ее в части этнокультурной нейтральности официального сегмента концепта «суд». Наоборот, для моделирования официального концепта «суд» в истории русского юридического языка сложился комплекс номинативных средств, имеющих высокую степень этнокультурной маркированности. Лингвокогнитивная и лингвокультурная интерпретация позволяет указать этнокультурные доминанты и их компоненты, актуализированные в данном концепте.

При интерпретации перечисленных этноконцептов в лингвокультурологических словарях эксплицируется их взаимосвязь, которую можно назвать когнитивной синкретсемией: правда - основная форма выражения справедливости, добра, праведности, она признается душой; справедливость - ощущение правды, побуждающее принимать праведное беспристрастное решение; праведность совестливость, честность, добродетельность; добро выражает правду, создает справедливость; совесть - способность души оценивать (судить) соответствие действий, событий по нравственной шкале добра и зла, то есть чувство справедливости, правды и чести, стремление к добру; душа в национальной системе нравственных ценностей предполагает сердечность, милосердие, совесть, стыд [Кобякова, 2004; Колесов, Колесова, Харитонов, 2014; Степанов, 2001]. С макроконцептами соотнесены микроконцепты морально-этической сферы: порядочность «совокупность высоких нравственных качеств, свойственных организованному человеку; включает понятие о чести, достоинстве, добре и справедливости в его душе, объединяя их в личностный “нравственный порядок”» [Колесов, Колесова, Харитонов, 2014 , т. 2, с. 65], честность - «совокупность безупречных душевных качеств человека чести как высшая ценность, исключающая хитрость, ложь и воровство», честный человек «...обладает благородством души, живет по законам совести и правды и неспособен на подлость (как бесчестный человек)... ничем морально не запятнанный и поэтому достойный почтения» [Колесов, Колесова, Харитонов, 2014, т. 2, с. 488-489].

При сопоставлении официального и обыденного сегментов концепта можно обнаружить сходство. В русской паремиологии о суде присутствуют нравственно и религиозно маркированные мелиоративные номинации с поясненной выше этнокультурной семантикой: правый суд (суд правый криваго дела не выправит), праведный судья (судия праведный - ограда каменна; праведный судия одесную Спасителя стоит; дарами и праведнаго судью к неправде приведешь) (Даль, с. 188-189; Снегирев, с. 83). В более многочисленных пословицах, негативно оценивающих судебную практику, актуализированы те же морально-этические этноконцепты, что в законодательстве (Бог любит праведника, а судья ябедника; неправдою суд стоит и др. (Даль, с. 189-190)), но при этом показано несоответствие эталону (пейоративная оценка). Поскольку юридическое и обыденное языковое сознание оперируют одними и теми же этнокультурными доминантами, эталонный образ правосудия совпадает. 
Л.В. Попова. Этнолингвокультурная специфика русского официального концепта «суд»

\section{Заключение}

Итак, на вербально-семантическом и лингвокогнитивном уровнях законодательных текстов, отражающих юридическое языковое сознание, мы наблюдаем активную трансляцию этнокультурных доминант при языковом формировании концепта «суд». Обнаруживается устойчивая связь морально-этических и юридических категорий: правосудие не отграничивается от принципов нравственного «кодекса», а опирается на него. В изученных законодательных документах, безусловно, сделан акцент на эталоне судебной системы, поэтому большая часть номинативных средств носит мелиоративный характер.

При сопоставлении официального сегмента концепта «суд» с обыденным сегментом концепта, выраженным в паремиологии, установлена общность этнокультурных доминант, что свидетельствует о совпадении профессионального и обыденного эталонного образа правосудия.

Проведенное исследование дает основания переоценить концепцию противопоставленности права и морали в отношении русского представления о правосудии: констатировать наличие общего эталона и различных акцентов в официальном (мелиоративного) и обыденном (пейоративного) сегментах концепта «суд», отражающих морально-правовой синкретизм.

\section{ПРИМЕЧАНИЕ}

${ }^{1}$ При ссылках на данное издание символ «№» используется для указания порядкового номера правового документа в сборнике.

\section{СПИСОК ЛИТЕРАТУРЫ}

Аругюнова Н. Д., 1999. Язык и мир человека. 2-е изд., испр. М. : Яз. рус. культуры. 896 с.

Воркачев С. Г., 2009. Правды ищи: идея справедливости в русской лингвокультуре : монография. Волгоград : Парадигма. 190 с.

Иванов В. В., Топоров В. Н., 1978. О языке древнего славянского права (к анализу нескольких ключевых терминов) // Славянское языкознание : докл. сов. делегации. VIII Междунар. съезд славистов (Загреб - Любляна, сент. 1978 г.)
/ редкол. : акад. В. И. Борковский [и др.]. М. : Наука. С. 221-240.

Карасик В. И., 2002. Языковой круг: личность, концепты, дискурс. Волгоград : Перемена. 477 с.

Касьянова К., 1994. О русском национальном характере. М. : Ин-т нац. модели экономики. 267 с.

Кобякова Т. И., 2004. Концепты духовности в русской языковой картине мира. Лингвокультурологический словарь. Уфа : Тип. ООО «Штайм». $158 \mathrm{c}$.

Колесов В. В., 2006. Русская ментальность в языке и тексте. СПб. : Петерб. востоковедение. 624 с.

Колесов В. В., Колесова Д. В., Харитонов А. А., 2014. Словарь русской ментальности : в 2 т. СПб. : Златоуст. Т. 1. 591 с. ; Т. 2.592 с.

Кузнецова Н. Ю., 2001. Фрагмент фрейма «суд» в немецком и русском паремиологическом фонде // Слово, высказывание, текст в когнитивном, прагматическом и культурологическом аспектах : тез. Междунар. науч.-практ. конф. (г. Челябинск, 7-9 дек. 2001 г.). Челябинск : Изд-во Челяб. гос. ун-та. С. 44-46.

Левонтина И. Б., Шмелев А. Д., 2000. За справедливостью пустой // Логический анализ языка : Языки этики. М. : Яз. рус. культуры. С. 281-292.

Лыкова Н. Н., 2005. Генезис языка права (на материале французских и русских документов $\mathrm{X}$ XV веков). Тюмень : Изд-во Тюмен. гос. ун-та. $308 \mathrm{c}$.

Степанов Ю. С., 2001. Константы : Словарь русской культуры. 2-е изд., испр. и доп. М. : Академ. Проект. 990 с.

\section{ИСТОЧНИКИ И СЛОВАРИ}

БЮС-Большой юридический словарь / В. Н. Додонов [и др.]. М. : Инфра-М, 2001. 790 с.

Даль - Даль В. Пословицы русскаго народа : сборник пословицъ, поговорокъ, реченій, присловій, чистоговорокъ, прибаутокъ, загадокъ, поверій. В 2 т. Т. 1. СПб. ; М. : Изданіе книгопродавцатипографа М.О. Вольфа, 1879.685 с.

ПРП - Памятники русского права : в 8 вып. / под ред. и с предисл. заслуж. деятеля науки проф. С. В. Юшкова. М. : Гос. изд-во юрид. лит., 1952-1961.

ПСЗРИ 1 - Полное собраніе законовъ Россійской Имперіи. Собраніе Первое. Съ 1649 по 12 Декабря 1825 года : в 42 т. СанктПетербургъ : Печатано въ Типографіи II Отд'九ленія Собственной Его Императорскаго Величества Канцеляріи, 1830.

$C A P$ - Словарь Академіи Россійской : в 6 ч. СанктПетербургъ : При Императорской Академїи Наукь, 1789-1794. 
СлРЯ XI-XVII-Словарь русского языка XI-XVII вв. 1975- . Вып. 1-29. М. : Наука, 1975-2011 ; Вып. 30. М. ; СПб. : Нестор-История, 2015.

СлРЯ ХVIII-Словарь русского языка XVIII века. 1984 . Вып. 1-6. Л. : Наука. Ленингр. отд-ние, 1984 1991 ; Вып. 7-19. СПб. : Наука. С.-Петерб. отд-ние, 1992-2011. URL: http://feb-web.ru/ feb/sl18/slov-abc/0slov.htm (дата обращения: 02.05.2020).

Снегирев - Снегирев И. Русскія народныя пословицы и притчи. М. : Въ Университетской типографіи, $1848.505 \mathrm{c}$.

СЦРЯ - Словарь церковно-славянскаго и русскаго языка, составленный Вторымъ отдњленіемъ Императорской Академіи наукъ : в 4 т. СанктПетербургъ : Въ Типографіи Императорской Академіи наукъ, 1847.

ТСДЮТ - Исаев М. А. Толковый словарь древнерусских юридических терминов : От договоров с Византией до уставных грамот Московского государства. М. : Спарк, 2001. 119 с.

\section{REFERENCES}

Arutyunova N.D., 1999. Yazyk i mir cheloveka [Language and the World of Man]. Moscow, Yazyki russkoy kul'tury Publ. 896 p.

Vorkachev S.G., 2009. Pravdy ishchi: ideya spravedlivosti $v$ russkoy lingvokul ture: monografiya [Seek the Truth: The Idea of Justice in Russian Linguistic Culture. Monograph]. Volgograd, Paradigma Publ. 190 p.

Ivanov V.V., Toporov V.N., 1978. O yazyke drevnego slavyanskogo prava (k analizu neskol'kikh klyuchevykh terminov) [On the Language of Ancient Slavic Law (To the Analysis of Several Key Terms)]. Borkovskiy V.I. et al., eds. Slavyanskoe yazykoznanie: dokl. sov. delegatsii. VIII Mezhdunarodnyy syezd slavistov (Zagreb - Lyublyana, sent. 1978 g.) [Slavic Linguistics: Reports of the Soviet Delegation. $8^{\text {th }}$ International Congress of Slavists (Zagreb - Lyublyana, September, 1978)]. Moscow, Nauka Publ., pp. 221-240.

Karasik V.I., 2002. Yazykovoy krug: lichnost', kontsepty, diskurs [Language Circle: Personality, Concepts, Discourse]. Volgograd, Peremena Publ. 477 p.

Kas'yanova K., 1994. O russkom natsional'nom kharaktere [On Russian National Character]. Moscow, Institut natsional'noy modeli ekonomiki. 267 p.

Kobyakova T.I., 2004. Kontsepty dukhovnosti v russkoy yazykovoy kartine mira. Lingvokul'turologicheskiy slovar' [Spirituality
Concepts in the Russian Language Picture of the World. Linguocultural Dictionary]. Ufa, Tipografiya OOO «Shtaym». $158 \mathrm{p}$.

Kolesov V.V., 2006. Russkaya mental'nost'v yazyke $i$ tekste [Russian Mentality in Language and Text]. Saint Petersburg, Peterburgskoe vostokovedenie Publ. 624 p.

Kolesov V.V., Kolesova D.V., Kharitonov A.A., 2014. Slovar' russkoy mental'nosti: $v 2 t$. [Dictionary of the Russian Mentality. In 2 Vols.]. Saint Petersburg, Zlatoust Publ., vol. 1. 591 p.; vol. 2. $592 \mathrm{p}$.

Kuznetsova N.Yu., 2001. Fragment freyma «sud» v nemetskom i russkom paremiologicheskom fonde [Fragment of the Frame "Court" in German and Russian Paremiology Foundation]. Slovo, vyskazyvanie, tekst v kognitivnom, pragmaticheskom i kul'turologicheskom aspektah: tez. Mezhdunar. nauch.-prakt. konf. (g. Chelyabinsk, 7-9 dek. 2001 g.) [Word, Utterance, Text in Cognitive, Pragmatic and Cultural Aspects. Theses of the International Scientific and Practical Conference (Chelyabinsk, December 7-9, 2001)]. Chelyabinsk, Izd-vo Chelyabinskogo gosudarstvennogo universiteta, pp. 44-46.

Levontina I.B., Shmelev A.D., 2000. Za spravedlivost'yu pustoy [Behind Empty Justice]. Logicheskiy analiz yazyka: Yazyki etiki [Logical Language Analysis: Ethics Languages]. Moscow, Yazyki russkoykul'tury Publ., pp. 281-292.

Lykova N.N., 2005. Genezis yazyka prava (na materiale frantsuzskikh $i$ russkikh dokumentov $X-X V$ vekov) [Genesis of the Language of Law (On the Material of French and Russian Documents of the $10^{\text {th }}-15^{\text {th }}$ Centuries)]. Tyumen, Izd-vo Tyumenskogo gosudarstvennogo universiteta. $308 \mathrm{p}$.

Stepanov Yu.S., 2001. Konstanty: Slovar' russkoy kul'tury [Constants: Dictionary of Russian Culture]. Moscow, Akademicheskiy Proekt Publ. 990 p.

\section{SOURCES AND DICTIONARIES}

Dodonov V.N., Ermakov V.D., Krylova M.A. et al. Bol'shoy yuridicheskiy slovar' [Big Legal Dictionary]. Moscow, Infra-M Publ., 2001. 790 p.

Dal' V. Poslovitsy russkago naroda: sbornik poslovits, pogovorok, recheniy, prisloviy, chistogovorok, pribautok, zagadok, poveriy. V 2 t. T. 1 [Proverbs of the Russian People: Collection of Proverbs, Adages, Saws, Redes, Pure Phrases, Jokes, Riddles, Beliefs. In 2 Vols. Vol. 1]. Saint Petersburg, Moscow, Izdanie knigoprodavtsatipografa M.O. Vol'fa, 1879.685 p. 
Л.В. Попова. Этнолингвокультурная специфика русского официального концепта «суд»

Yushkov S.V., ed. Pamyatniki russkogo prava: $v 8$ vyp. [Written Documents of Russian Law. In 8 Iss.]. Moscow, Gosudarstvennoe izd-vo yuridicheskoy lileratury, 1952-1961.

Polnoe sobranie zakonov Rossiyskoy Imperii. Sobranie Pervoe. S 1649 po 12 Dekabrya 1825 goda: $v 42 t$. [Complete Collection of Laws of the Russian Empire. First Collection. From 1649 to December 12, 1825. In 42 Vols.]. Saint Petersburg, Pechatano v Tipografii II Otdeleniya Sobstvennoy Ego Imperatorskogo Velichestva Kantselyarii, 1830.

Slovar' Akademii Rossiyskoy: v 6 ch. [Dictionary of the Russian Academy. In 6 Parts]. Saint Petersburg, Pri Imperatorskoy Akademii Nauk, 1789-1794.

Slovar' russkogo yazyka XI-XVII vv. [Dictionary of the Russian Language of the $11^{\text {th }}-17^{\text {th }}$ Centuries], iss. 1-29. Moscow, Nauka Publ., 1975-2011; iss. 30. Saint Petersburg, NestorIstoriya Publ., 2015.

Slovar' russkogo yazyka XVIII veka [Dictionary of the Russian Language of the $18^{\text {th }}$ Century], iss. 1-6. Leningrad, Nauka, Leningradskoe otdelenie Publ., 1984-1991; iss. 7-19. Saint Petersburg, Nauka, Sankt-Peterburgskoe otdelenie Publ., 1992-2011. URL: http://febweb.ru/feb/sl18/slov-abc (accessed 2 May 2020).

Snegirev I. Russkiya narodnyya poslovitsy i pritchi [Russian Folk Proverbs and Parables]. Moscow, V Universitetskoy tipografii, 1848. $505 \mathrm{p}$.

Slovar' tserkovno-slavyanskago i russkago yazyka, sostavlennyy Vtorym otdeleniem Imperatorskoy Akademii nauk: $v 4 t$. [Dictionary of the Church Slavonic and Russian Language, Compiled by the Second Division of the Imperial Academy of Sciences. In 4 Vols]. Saint Petersburg, V Tipografii ImperatorskoyAkademii nauk, 1847.

Isaev M.A. Tolkovyi slovar' drevnerusskikh yuridicheskikh terminov: Ot dogovorovs Vizantiey do ustavnykh gramot Moskovskogo gosudarstva [Explanatory Dictionary of Ancient Russian Legal Terms: From Contracts with the Byzantine Empire to the Charters of the Moscow State University]. Moscow, Spark Publ., 2001. 119p.

\section{Information About the Author}

Lyudmila V. Popova, Candidate of Sciences (Philology), Associate Professor, Department of Philology, Miass branch of Chelyabinsk State University, Kerchenskaya St, 1, 456313 Miass, Russia, mila_fil@mail.ru, filial_chelsu@mail.ru, https://orcid.org/0000-0003-2690-246X

\section{Информация об авторе}

Людмила Викторовна Попова, кандидат филологических наук, доцент кафедры филологии, Миасский филиал Челябинского государственного университета, ул. Керченская, 1, 456313 г. Миасс, Россия, mila_fil@mail.ru, filial_chelsu@mail.ru, https://orcid.org/0000-0003-2690-246X 